\title{
ЛІНГВОКОГНІТИВНІ МЕХАНІЗМИ ПОРОДЖЕННЯ ОДИНИЦЬ ВТОРИННОЇ ФРАЗЕОЛОГІЗАЦІЇ (НА МАТЕРІАЛІ ФРАНЦУЗЬКОЇ МОВИ)
}

\section{Мойсюк В. А.}

\section{ВСТУП}

Для позначення нових реалій або нової категоризації і концептуалізації дійсності номінатори, використовуючи наявні в мові одиниці й застосовуючи мовні закони їхньої комбінаторики, змушені часто вдаватися до породження інновацій, розширюючи знаковий масив мови. Водночас динаміка і здатність до неологізації останньої дає змогу їй виконувати дедалі складніші когнітивно-дискурсивні функції, сприяючи відображенню у свідомості носіїв мови явищ навколишньої дійсності. Отже, оновлення мови пов'язане із внутрішньою мотивацією процесу вербалізації продуктів пізнання, а також із факторами когнітивнокомунікативного та дискурсивно-прагматичного характеру, які зумовлюють породження нової одиниці різними способами інтелектуальної та емотивно-оцінної активності мовців.

Основними виявами цього процесу $\epsilon$ первинна та вторинна фразеологізації, які показують креативні механізми етносвідомості, ускладнення категоризації емпіричного та рефлексивного досвіду, концептуальне переосмислення дійсності, динаміку оцінного, ціннісного й культурного іiі сприйняття. Але якщо перший спосіб породження фразеологічних одиниць (далі - ФО) часто привертає увагу дослідників різних наукових шкіл (М. Алефіренко, М. Болдирев, О. Брагіна, В. Костомаров, О. Кравченко, О. Кубрякова, Р. Намітокова, O. Сенько, С. Тогоєва, М. Шанський, Ch. Gledhill, P. Frath, J. Pruvost та ін.), то явище вторинної фразеологізації розглядається лише в поодиноких працях, присвячених, зокрема, закономірностям та шляхам виникнення у мові фразеологічних дериватів (Ю. Гвоздарев, С. Денисенко, Д. Добровольський, Ю. Караулов, Н. Керимзаде, О. Кунін, В. Мокієнко, I. Чернишова, U. Bähler, H. Burger, G. Haßler, Ch. Hümmer та ін.).

Однак поява нових лінгвістичних парадигм (когнітивна лінгвістика, лінгвокультурологія, дискурсивний аналіз тощо) відкриває перед фразеологами перспективні напрями, вимагає застосування нестандартних підходів до осмислення й опису механізмів породження 
нових фактів у мові й мовленні. Тому особливо актуальними видаються нам дослідження інновацій 3 позицій когнітивної лінгвістики, яка розглядає явища неологізації у тісному зв'язку із духовно-практичною діяльністю людини, мисленням і культурою, тобто 3 тими внутрішньолінгвальними та екстралінгвальними факторами, які й визначають лінгвокогнітивну діяльність людини.

Mema запропонованої розвідки - визначення лінгвокогнітивних механізмів породження одиниць вторинної фразеологізації у сучасній французькій мові. Основне завдання полягає у розкритті сутності вторинної фразеологізації та іiі відокремлення від інших явищ фразеотворення, а також у виявленні основних модифікацій, задіяних у цьому процесі, з когнітивної точки зору.

Матеріалом дослідження слугували 342 неологічні ФО, відібрані із центральних періодичних видань сучасної французької мови (Le Parisien, Le Figaro, Le Monde, Le Point, L'express, La libération тощо).

Поставлені в дослідженні мета й завдання зумовили використання таких лінгвістичних методів, як: неофразеологічний опис для ідентифікації неологічних ФО, аналіз контекстуального оточення для виявлення інноваційних зсувів у дискурсивно-смисловому змісті досліджуваних одиниць, характеру взаємодії фразеологічних компонентів, а також встановлення ступеня закріпленості складу та структури неологічних ФО, когнітивний аналіз для моделювання процесу породження нового концептуального значення шляхом побудови інтегрованого простору (далі - IП), визначення лінгвокогнітивних механізмів вторинної фразеологізації, опису основних когнітивних моделей, які детермінують характер взаємозв'язку між вихідними ментальними просторами (далі - МП), а також кількісні підрахунки для практичного підтвердження висловлених у роботі теоретичних положень.

\section{1. Визначення поняття вторинної фразеологізації}

Ще закладаючи основи сучасної теорії фразеології, Ш. Баллі звернув увагу на зміни в усталених словесних комплексах. Вивчаючи фразеологічні єдності, у яких поглинається i втрачається індивідуальний смисл слів-компонентів, він зазначав, що «фразеологічний зворот може містити, крім постійної частини, також змінну, тобто деякі слова звороту можуть бути замінені іншими без порушення цілісності групи» ${ }^{1}$. I справді, фразеологічній системі будьякої мови характерна лише відносна стабільність, а пї межі визначаються лише умовно на певний момент розвитку мови.

${ }^{1}$ Bally Ch. Traité de stylistique française. Genève, 1951. S. 74. 
Закріпившись у мові після стадій індивідуалізації та соціалізації, пройшовши випробовування часом, узуальні ФО через певний проміжок часу починають модифікувати свою форму, виявляючи природні та необхідні властивості, які, власне, й забезпечують спосіб їхнього існування в мові та функціонування в мовленні.

Водночас, виходячи із розуміння деривації загалом як процесу творення мовних одиниць, які відбуваються на рівні мовленнєвомисленнєвої діяльності людини, науковці вибирають об'єктом своїх досліджень увесь комплекс новоутворень на базі фразеології, включаючи як утворення нових слів, омонімів, складних слів, так і нових ФО. У зв'язку із цим постає питання термінологічного розмежування двох різних процесів: 1) утворення нових слів або значень від узуальних ФО та 2) утворення неологічних ФО від узуальних ФО. За першим типом деривації у мовознавстві закріплюють, відповідно, термін словотвірна деривачія на базі фразеологіï, а за другим - фразеологічна деривація, яку витлумачують як один із процесів фразеотворення, за якого під впливом лінгвальних та екстралінгвальних чинників, через модифікації у семантиці, структурі та граматичному оформленні початкових ФО, формуються похідні ФО, тобто фразеологічні деривати ${ }^{2}$.

Досліджуючи фразеологічну деривацію із функціонального погляду,

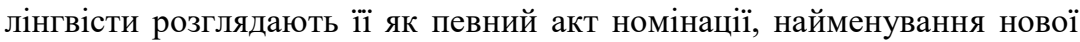
для соціального або індивідуального досвіду реалії або поняття на основі вже відомої, і позначають іiі терміном третинна номінаиія, а фразеологічні деривати, значення яких детерміноване значенням їхніх фразеологічних прототипів, називають знаками третинної номінації ${ }^{3}$. У цьому контексті увагу науковців зосереджено загалом на руйнівній (дестабілізувальній) функції модифікацій (А. Chauvin, M. Dumas, A. Goulet, A. Juillard, M. Riffaterre та ін.), рідше на їхній «породжувальній» функції (R. Amossy, U. Bähler, A. Didier, E. Rosen та ін.). Так, франкомовна дослідниця У. Бахлер, розмірковуючи над модифікаціями ФО, співвідносить два дискурсивні світи - «світджерело» і «світ-ціль», перший з яких відповідає вже реалізованому

Денисенко С.Н. К вопросу взаимосвязи слово- и фразообразования. Филологические науки. 1985. № 1. С. 55; Джаграева М.Л. Коммуникативнопрагматические особенности фразеологической деривации : дис. на соискание науч. степени канд. филол. наук : спец. 10.02.19 «Теория языка». Ставрополь, 2005. С. 41. URL: http://cheloveknauka.com/.

3 Кунин А.В. Курс фразеологии современного английского языка. Москва, 1996. C. 182. 
дискурсивному світу, а другий ототожнюється з іще невідомим світом, який реферує до першого, змінюючи його ${ }^{4}$.

Характеризуючи систему мови як сукупність комунікативних засобів, деякі лінгвісти розглядають фразеологічну деривацію як певний момент мовної комунікації, роль якої особливо зростає у зв'язку із текстотворенням. Текстову значущість похідних ФО визначено в такому разі новизною об'єкта і характером інформації, яка передається. У процесі комунікації узуальні ФО, незважаючи на свою усталеність, зазнають різних модифікацій, підкорюючись різним інтенціям автора й органічно вписуючись в індивідуально-авторську картину світу ${ }^{5}$.

Представлене в нашому дослідженні когнітивне вивчення неологічних ФО уможливлює висвітлення, з одного боку, когнітивного потенціалу узуальної фразеології, а з іншого - з'ясування креативних мовленнєвопороджувальних здатностей носіїв мови, які прагнуть до максимально точного вираження думки й до чітко визначеного відображення навколишнього середовища. При цьому вважаємо доцільним вести мову про вторинну фразеологізацію, протиставляючи іiі первинній, якій властиві інші когнітивні процеси та ономасіологічні принципи творення. Така позиція зумовлена також чітким окресленням об'єкта нашого дослідження: під результатами фразеологічної деривації науковці розуміють усі типи дериваційних одиниць (узуальні, потенційні, оказіональні, авторські неологізми, структурно-семантичні варіанти тощо), тоді як ми концентруємо свою увагу лише на тих новотворах, які претендують на статус неологічних ФО. Останні ми витлумачуємо як відтворювані усталені словосполучення або речення, нові за значенням або за формою i значенням, породжені за структурно-синтаксичними моделями досліджуваної мови, або запозичені з іншої мови за потреб спілкування, або модифіковані на основі узуальних ФО, або активовані, або детермінологізовані впродовж останніх 20 років стосовно періоду їх дослідження 3 можливою фіксацією у словниках нових виразів.

Під час вивчення природи одиниць вторинної фразеологізації постає питання їхнього виокремлення від інших фразеологічних інновацій. По-перше, 3 окресленим явищем тісно пов'язана фразеологічна варіативність, яка присутня у кожній мові. Важливу роль у розумінні

4 Bähler U. Réflexions à partir de renouvellements de locutions stéréotypées. Languages. 2000. No. 137. P. 47. URL: www.persee.fr.

5 Колшанский Г.В. Соотношение субъективных и объективных факторов в языке. Москва, 1975. 232 с.; Красных В.В. Этнопсихолингвистика и лингвокультурология. Москва, 2002. 284 с. 
механізму варіювання ФО грають, за словами П. Флоренського, протиріччя на рівні мови та мовлення, а саме: усталеність/неусталеність, відтворюваність/ невідтворюваність, загальне/індивідуальне, синхронія/діахронія, імпліцитність/ експліцитність ${ }^{6}$. У контексті фразеологічної деривації О. Кунін послуговується терміном структурно-семантична варіативність, під якою розуміє «контекстуально детерміновані модифікації зовнішньої або внутрішньої форми ФО, використані мовцем для адекватнішої передачі його думки та реалізації певної комунікативної мети» ${ }^{7}$. Дозволимо собі не погодитися з такою позицією науковця і вважати варіантом узуальної ФО модифіковану форму, яка не зазнає семантичних змін. У разі ж отримання нею додаткового компонента у семантичному значенні iï можна розглядати як неологічну ФО. Тому досить важливим для нас $\epsilon$ розмежування понять фразеологічної варіативності та фразеологічного перетворення, наслідком якого $€$ породження неологічних ФО.

Отже, сутність фразеологічної варіативності полягає в тому, що під впливом екстралінгвальних чинників ФО видозмінює свою форму, визнану носіями певної мовної спільноти як прототипну (канонічну). При цьому варіант і канонічна ФО мають однакове ідіоматичне значення і однакове позначуване, хоча й різняться парадигматичним $\mathrm{i} / \mathrm{aбо} \mathrm{синтагматичним} \mathrm{поширенням}{ }^{8}$. Так, 3 однаковим семантичним значенням функціонують фразеологічні варіанти transpirer à grosses gouttes i suer à grosses gouttes «сильно пітніти», avoir le vin joyeux i avoir

\footnotetext{
${ }^{6}$ Флоренский П.А. Термин. Вопросы языкознания. 1989. № 1. С. 123.

${ }^{7}$ Кунин А.В. Курс фразеологии современного английского языка. Москва, 1996. C. 57.

${ }^{8}$ Мізін К.І. Компаративні фразеологічні одиниці сучасної німецької мови: шляхи утворення та ідеографія : автореф. на здобуття наук. ступеня канд. філол. наук : спец. 10.02.04 «Германські мови». Київ, 2004. 20 с.; Пташник С.Б. Фразеологічні модифікації: термінологічні проблеми. Вісник Львів. ун-ту. Серія Іноземні мови. 2011. Вип. 9. С. 112-120; Телия В.Н. Русская фразеология. Семантический, прагматический и лингвокультурологический аспекты. Москва, 1996. 288 с.; Чередниченко В.О. Інноваційна фразеологічна вербалізація в англійській мові (лінгвокогнітивний та соціолінгвістичний параметри) : дис. на здобуття наук. ступеня канд. філол. наук : спец. 10.02.04 «Германські мови». Запоріжжя, 2005. 220 c. URL: http://www.allbest.ru/; Bolly C. Les unités phraséologiques: un phénomène linguistique complexe?: thèse de doctorat. Louvain-la-Neuve, 2008. 344 p.; Curat H. Les déterminants dans la référence nominale et les conditions de leur absence. Genève, 1999. 350 p.; Klein J.R. Le figement dans les proverbes et les expressions verbales: un débat qui n'est pas encore ... figé. Nouveaux apports à l'étude des expressions figées / Conde Tarrío G. Cortil-Wodon. 2007. P. 129-156; Haßler G., Hümmer Ch. Figement et défigement polylexical: l'effet des modifications dans des locutions figées. Linx: Revue des linguistes de l'université Paris $X$. 2005. No. 53: Le semi-fegement. P. 103-119.
} 
le vin gai «веселитися в стані легкого сп'яніння». Поява варіантів може бути зумовлена регіональним або функціональним уживанням, наприклад: французька ФО prendre position «займати певну позицію» має бельгійський варіант prendre attitude; розмовна ФО bouger ses fesses «танцювати» отримує арготичний варіант bouger sa boule. Комунікативно-прагматичні наміри мовців, зокрема пародіювання, також можуть сприяти варіюванню канонічних ФО, наприклад: на основі паремії Pierre qui roule n'amasse pas mousse «невпорядковане життя, повне пригод, не дозволяє накопичити гроші» утворив фразеологічний варіант Bière qui mousse n'a plus de goût 3 тим же значенням, але з іншим образом в основі, більш близьким для сучасних представників франкомовної спільноти. Прикладом того, що модифікований варіант може навіть витіснити з ужитку узуальну ФО, слугує утворена внаслідок антонімічної заміни ФО être comme un poisson dans l'eau «почуватися невимушено», яка із XVIII ст. вживалася паралельно зі своїм прототипом être comme un poisson hors de l'eau, a пізніше сприяла тому, що остання перейшла до категорії застарілої лексики. Водночас поняття узуального вживання є досить відносним, оскільки визначення прототипної форми, по-перше, базується на нормативному виборі, а по-друге, залежить від когнітивнопрагматичних чинників комунікації та частоти вживання.

У цій площині перед науковцями постає також питання відокремлення понять варіативності та синонімії. Під синонімічними фразеологічними утвореннями вони розуміють «два звороти, різні за лексичним складом компонентів, але однотипні за категорійним граматичним значенням, які здатні до заміни у певних синтаксичних конструкціях, але які не порушують будову цієї конструкції та іiі змісту» ${ }^{9}$ або одиниці, які «характеризуються спорідненістю фразеологічних значень, але різняться етимологічними образами та експресивно-емоційними властивостями» ${ }^{10}$. Однак фразеологічні варіанти також витлумачують як «одиниці, що варіюють, але не змінюють при цьому семантику, валентність, образ і функціональностилістичну належність ФО» ${ }^{11}$, або як «різновид ФО, тотожних за стилістичними функціями, якістю і кількістю значень, або одиниці, що мають спільну інваріантну лексему у разі частково відмінного лексичного складу, або ті, що відрізняються словоформами або

${ }^{9}$ Телия В.Н. Что такое фразеология? Москва, 1966. С. 77.

${ }^{10}$ Уманець А., Стадник О. Типологічні особливості фразеологічних синонімів в англійській та українській мовах. Наукові праці Кам'янець-Подільського держ. пед. ун-ту. Філологічні науки. Кам'янець-Подільський, 2001. Вип. 5. С. 49.

11 Баран Я.А. Фразеологія у системі мови : монографія. Івано-Франківськ, 1997. C. 99. 
порядком слів» ${ }^{12}$. Окреслені два явища - варіативність та синонімія наділені також однаковими функціями і дискурсивним навантаженням: «Синонімічні ФО - дуже потужний і дієвий стилістичний засіб, оскільки за їх допомогою можна образно чи експресивно передати найтонші відтінки значення, найвлучніше охарактеризувати об'єкт відповідно до мети спілкування» ${ }^{13}$.

По-друге, від вторинної фразеологізації варто відрізняти оказіональне вживання узуальних ФО. На цьому, власне, наполягають ті лінгвісти, які розмежовують узуальну та оказіональну варіативність: перша продиктована мовною системністю, нормою вживання $\Phi О$, а друга залежить не від обмеженого мовною системою кола слів, а від семантичних і стилістичних намірів індивіда ${ }^{14}$. Побудовані на обіграванні співвідношення фразеологічної похідної основи і похідного оказіонального словосполучення та зумовлені прагматикою мовленнєвого акту (пошук експресії, бажання надати висловленню яскравіших і переконливіших ознак), трансформації породжують тимчасові одиниці ad hoc, призначені для певного контексту. Так, деякі ФО здатні утворювати синонімічні серії шляхом субституції одного або більше елементів типу пe pas/plus avoir la tête à ce qu'on fait або акціональні серії типу arriver/être comme un chien dans un jeu de quilles. Незважаючи на те, що основну масу таких варіантів уже лексикалізовано, їх можна інтерпретувати, на наш погляд, лише як відносно узуальні.

Цікавими в цьому контексті є міркування М. Шанського, на думку якого «незначна зміна складу фразеологічного звороту породжує фразеологічний неологізм <...>. Будь-яка модифікація у складі ФО, будь-яка навіть найменша зміна порядку слідування компонентів усвідомлюється мовцями як новоутворення» ${ }^{15}$. Важко погодитися із таким безапеляційним твердженням дослідника, адже, незважаючи на «свіжість» і «незвичність» модифікованої узуальної ФО, вона може й не отримати статус неологічної ФО, залишаючись у межах поля оказіональних утворень.

Зазначимо також, що поява оказіональних ФО може відбуватися як стихійний процес, який виникає у мовленні спонтанно під впливом

12 Биренбаум Я.Г., Сидякова Н.М. Отражение вариантности фразеологических единиц в словаре устойчивых сравнений английского языка. Вариативность в германских языках : тезисы докладов и сообщений Всесоюз. конф. Калинин, 1988. С. 185.

${ }^{13}$ Васильченко В. Українська фразеологія. Київ, 2000. С. 27.

${ }^{14}$ Копыленко М.М., Попова З.Д. Очерки по общей фразеологии. Воронеж, 1972. 124 с.; Ханпира Э. Об окказиональном слове и окказиональном словообразовании. Развитие словообразования современного русского языка : сб. науч. тр. М., 1966. С. 153-166.

${ }^{15}$ Шанский Н.М. Лексикология современного русского языка. Москва, 1972. С. 22. 
різних психолінгвальних факторів (неграмотність, хвилювання, поспіх тощо), i, як наслідок, не усвідомлюється мовцем. Нас же цікавлять ті трансформації ФО, які запрограмовані його когнітивною діяльністю, створені свідомо й цілеспрямовано.

По-трете, в працях сучасних науковців поняття варіативності ФО тісно пов'язане з нормативним і звичним для контекстуальної семантики явищем дефразеологізації. Виявляючи динамічний характер і креативну потенційність мови, воно реалізується за допомогою ремотивації або делексикалізації усталеного вислову. Інакше кажучи, в дефразеологізованій ФО ідіоматичне значення нашаровується на композиційне значення компонентів, у результаті чого уможливлюється подвійне семантичне прочитання. Р. Галіссон, наприклад, порівнює процес дефразеологізації із палімпсестом, первинний текст якого був стертий, а потім замінений на інший, або ж із лусковим покриттям, у якому на лексикалізований під-вислів нашаровується над-вислів, утворений унаслідок реконструкції основного під-вислову ${ }^{16}$. Не вдаючись у детальний опис цього явища, зауважимо, що серед основних прийомів дефразеологізації науковці називають парадигматичну субституцію одного із компонентів усталеного вислову, полісемантичну гру через вплив ко(н)тексту на семантику одного із компонентів, модифікацію синтагматичної комбінаторики через вклинювання, розширення або еліпсис одного із компонентів, морфосинтаксичну модифікацію через зміну категорійних ознак ${ }^{17}$. Водночас подібні трансформації спостерігаємо під час процесу вторинної фразеологізації, що зумовлює плутанину між цими двома явищами.

Тому підкреслимо ще раз, що дефразеологізацію спрямовано на руйнування ідіоматичного значення для створення комічного, парадоксального ефекту, тоді як результатом вторинної фразеологізації $\epsilon$ поява неологічних ФО з новим значенням або з новим значенням і новою формою. Саме цей факт - породження нового концептуального змісту - вирізняе вторинну фразеологізацію від подібних до неї явищ фразеологічної варіативності, оказіонального вживання та дефразеологізації.

\section{2. Структурний та змістовий аспекти породження неологічних ФО}

Вивчення сутності вторинної фразеологізації поставило перед лінгвістами також питання визначення структурного та змістового

${ }^{16}$ Galisson R. Les palimpsestes verbaux: des révélateurs culturels remarquables mais peu remarqués. La locution en discours. Cahiers du français contemporain. 1995. No. 2. P. 45-46.

${ }^{17}$ Bolly C. Op. cit. C. 32-33. 
аспектів породження неологічних ФО. Із функціонально-семантичної точки зору, залежно від кількості новоутворених ФО та ступеня продуктивності їхього творення, дослідники поділяють структурні типи фразеологічної деривації, відповідно, на одноразову або багаторазову, на лінійну або об'ємну деривації ${ }^{18}$.

Застосування запропонованої науковцями класифікації до аналізу неологічних ФО сучасної французької мови показало, що iі типи перехрещуються між собою, внаслідок чого можемо виокремити такі типи вторинної фразеологізації, як:

1) одноразова лінійна, за якої деривація відбувається за схемою «узуальна ФО $\rightarrow$ неологічна ФО», наприклад: похідна ФО les absents ont toujours tort отримала узагальнене й абстрактне значення «треба бути присутнім, щоб відстоювати свої інтереси» на базі усталеного виразу les os pour les absents «або обідаємо без них, або залишаємо їм лише об'їдки», який завдяки конотаціям іменника os «кістка» виражав черствість і егоїзм у соціальних відношеннях, що панували у суспільстві XVIII ст.; неологічну ФО oeil noir «погляд, що виражає сильний гнів» утворено від узуальної колокації colère noire «сильний гнів»;

2) багаторазова лінійна, якій властиві кілька ступенів деривації, реалізованих за схемою «узуальна $Ф О \rightarrow$ неологічна $\Phi О \rightarrow$ неологічна ФО», наприклад: на основі узуальної ФО Accorder vos violons! «Домовляйтеся!» утворений був спочатку дієслівний вираз accorder vos flûtes «погодити різні думки», від якого, своєю чергою, утворено іменниковий вираз accordeur de flutes «мировий суддя»; подібним чином, але у зворотному напрямку, породжено дієслівну неологічну ФО transmettre de bouche à oreille «поширювати чутки» від прислівникової неологічної ФО de bouche à oreille «пошепки; потайки», яку було утворено на базі іменникової узуальної ФО bouche à oreille «чутки»;

3) одноразова об’ємна, за якої від однієї узуальної ФО утворено кілька неологічних ФО за схемою «узуальна $Ф О \rightarrow$ неологічна $\Phi_{1}+$ неологічна $\Phi \mathrm{O}_{2} »$, наприклад: узуальна $Ф О$ l'argent n'a pas d'odeur «гроші не пахнуть» породила дві неологічні ФО 3 ідентичним значенням, але з різним вираженням відношень між компонентами у середині асоціативного поля: ФО 1 l'or n'a pas d'odeur (родо-видові зв'язки) та $\Phi \mathrm{O}_{2}$ l'argent ne sent rien (причинно-наслідкові зв'язки); на базі узуальної ФО monter une pièce «поставити п’єсу (на сцені)» 3'явилися три неологічні ФО, зокрема: monter une histoire «вигадати вишукану брехню», monter une patate «обманювати з інсценуванням»

${ }^{18}$ Денисенко С.Н. Вказ. пр. 1985; Джаграева М.Л. Вказ. пр. 
i monter un bateau [une vanne] «влучно збрехати», кожна 3 яких актуалізує інші образи;

4) багаторазова об'ємна, за якої одна ФО є одночасно джерелом виникнення іншої $Ф О$, яка, своєю чергою, стає твірною для кількох ФО за схемою «узуальна $Ф О \rightarrow$ неологічна $\Phi О \rightarrow$ неологічна $\Phi_{1}+$ неологічна $\Phi \mathrm{O}_{2} »$, наприклад: від узуальної ФО mettre un coup de poing «побити» шляхом заміни іменникового компонента утворилася неологічна ФО 3 пейоративною конотацією mettre une patate «відлупцювати», від якої, своєю чергою, утворилися ще дві неологічні одиниці - ФО ${ }_{1}$ mettre la patate «робити зусилля, робити якомога краще» (шляхом морфологічної заміни) та $\Phi_{2}$ mettre la carotte «застосувати насилля; заставити себе поважати» (шляхом заміни компонента).

У такий спосіб породжуються деривативно пов'язані фразеологічні серії, одне із завдань яких полягає не лише в експресивно-емоційній номінації об'єкта, а й у логічному уточненні інформації про нього, виокремленні нових ознак завдяки утворенню нового образу тощо.

Щодо трансформацій, які супроводжують фразеологічну деривацію, то лінгвісти поділяють їх на два основні типи: 1) семантичні перетворення, які не порушують лексико-граматичну структуру твірної $\Phi О$, a переосмислюють, оновлюють іï семантику (подвійна актуалізація, буквалізація значення, народно-етимологічне переосмислення внутрішньої форми, антонімічний розвиток образу, перефразування, семантичне оновлення тощо), та 2) структурносемантичні перетворення, пов'язані з формальними змінами твірної $Ф О$, тобто ті, що трансформують іiі компонентний склад і граматичну структуру, видозмінюючи при цьому ії семантичне значення (редукція, розгортання структури, модернізація, морфологічні трансформації, контамінація, конверсія, аналогія, перерозподіл, відокремлення компонентів, зміна компонентів, змішування прийменників у складі ФО, перерозподіл тощо) $)^{19}$.

Дослідження явища вторинної фразеологізації з когнітивної точки зору дозволило нам визначити лінгвокогнітивні механізми породження неологічних ФО французької мови, які відбуваються безпосередньо в межах усталеного виразу, а також проаналізувати лінгвокогнітивні моделі творення їхнього нового концептуального змісту. Нами виокремлено структурно-семантичні та семантичні модифікації, за допомогою яких утворено, відповідно, 259 неологічних ФО (76\%) та

${ }^{19}$ Кунин А.В. Вказ. пр.; Ларин Б.А. Очерки по фразеологии (О систематизации и методах исследования фразеологических материалов). История русского языка $u$ общее языкознание. Москва, 1977. С. 125-149; Чередниченко В.О. Вказ. пр.; Curat H. Op. cit. 
83 неологічні ФО (24\%). При цьому наголосимо ще раз, що основною їхньою характеристикою $є$ максимальна семантичність. Інакше кажучи, саме семантична зміна $є$ однією 3 обов'язкових умов процесу фразеологічної деривації і супроводжує всі іï різновиди, на чому, власне, наголошували ще представники функціонально-семантичної парадигми ${ }^{20}$.

Структурно-семантичні модифікації завдячують не лише особливому, незвичному контекстному вживанню узуальних ФО, а й їхній мовно-мовленнєвій природі. Найяскравіше вони виявляються у структурі фразеологічних сполучень - колокацій різного ступеня усталеності. Це пояснюється насамперед тим, що саме в них складники, хоча й залишаються фразеологічно зв'язаними, характеризуються значно більшою самостійністю, ніж в ідіомах, що й дозволяе мовцю порушувати закони семантичних зв'язків, властиві певній мові. Але й ідіоми, яким властива некомпозиційність значення, можуть інколи зазнавати змін, оскільки їхні значення певною мірою мотивовані окремими значеннями їхніх складників.

Детальне вивчення структурно-семантичних модифікацій у ході породження нових ФО з точки зору побудови ІП дозволило нам виявити такі когнітивні процеси, як:

1) ампліфікація (117 ФО - 45\%) - заміна одного або кількох МП узуальної ФО на інший, пов'язаний із ними асоціативно. Залежно від типу взаємозв'язку вихідних і введених МП, виокремлюємо три типи ампліфікації, а саме: метонімічну ампліфікацію, напр.: passer à tabac «допитувати; відлупцювати» $\rightarrow$ passage à tabac «жорстка санкція; фізичне насилля», casser la baraque «зруйнувати встановлений порядок» $\rightarrow$ sauver la baraque «спасти ситуацію»; метафоричну ампліфікацію, напр.: se prendre une tête «ускладнювати собі життя» $\rightarrow$ prendre un melon «сердитися», croqueuse de diamants «жінка, яка полює за грошима» $\rightarrow$ croqueuse d'hommes «звабниця»; іншомовну ампліфікацію, напр.: faire sa vie «влаштовувати своє життя» $\rightarrow$ faire sa life «влаштовувати своє приватне життя», faire monter les ventes «збільшувати продаж» $\rightarrow$ booster les ventes «прискорювати продаж (у разі його повного падіння)»;

2) доповнення (76 ФО - 29\%) - введення до структури узуальної ФО додаткового МП, внаслідок чого в ІП з'являється, зокрема, новий

20 Денисенко С.Н. Фразеологическая деривация как системный и коммуникативный феномен : дисс. на соискание науч. степени док. филол. наук : спец. 10.02.04 «Германские языки». Львов, 1993. С. 14; Джаграева М.Л. Вказ. пр.; Керимзаде Н.К. Фразеологическая деривация : автореф. дисс. на соискание науч. степени канд. филол. наук : спец. 10.02.04 «Германские языки». Москва, 1984. С. 7. 
образ виконуваної дії або стану, напр.: les sentiers battus «проторений шлях» $\rightarrow$ s'écarter des sentiers battus «відхилитися від спільного рішення»; образ ознаки об'єкта номінації, напр.: chair à pâté «фарш» $\rightarrow$ haché comme chair à pâté «побитий; важко поранений»; образ нового сценарію, напр.: Qui cherche trouve «Хто шукає, той знайде» $\rightarrow$ Qui cherche trouve et qui trouve supporte «Ініціативу карають»; образ виконавця діï, напр.: pain de fesse «виторг сутенера» $\rightarrow$ profiteur de pain de fesse «сутенер»;

3) елімінація (20 ФО - 8\%) - виведення одного або кількох МП зі структури узуальної ФО, що зумовлюе два шляхи розвитку концептуального змісту, а саме: категорійну трансформацію, напр.: s'en aller en eau de boudin «зазнати невдачі» $\rightarrow$ eau de boudin «безцінний предмет», tuer la poule aux oufs d'or «вбити курку, яка несе золоті яйця» $\rightarrow$ poule aux oufs d'or «постійне джерело доходів»; зміну значення в напрямку «конкретне значення $\rightarrow$ узагальнене значення», напр.: manger son pain blanc le premier «бути необачним» $\rightarrow$ manger son pain blanc «пережити найбільш сприятливий період», Tout est bien qui finit bien «Все добре, що добре закінчується» $\rightarrow$ Tout est bien qui finit «Все добре, що закінчується»;

4) калькування (19 ФО - 7,5\% - буквальний переклад компонентів іншомовних ФО і подальше складання їх за законами мови-позичальниці; цей процес супроводжується перенесенням образів МП іншомовних компонентів, які їм близькі або ідентичні за значенням, або запозиченням їхньої синтаксичної структури, що дозволяє виокремити три типи фразеологічних кальок, а саме: семантичні, напр.: англ. white collar $\rightarrow$ фр. col blanc «службовець», англ. conventional weapons $\rightarrow$ фр. armement conventionnel «неядерна класична зброя»; семантико-синтаксичні, напр.: англ. pole position $\rightarrow$ фp. pole position «вигідне, виграшне положення», англ. to be justified in smth $\rightarrow$ фp. être justifié de qqch «мати докази»; формальні, напр.: англ. roadmap $\rightarrow$ фр. feuille de route «проєкт політичної боротьби; план урегулювання конфлікту; програма розвитку проєкту», англ. $Z$ movie $\rightarrow$ фp. film de série $\boldsymbol{Z}$ «фільм з низьким бюджетом і поганої якості»;

5) граматична трансформація $(18$ ФО - 7\% $\quad$ - процес «висвічування» інших образів МП узуальних ФО шляхом зміни категорійних ознак дієслівного та іменникового компонентів (напр.: peindre qqn en јаune «обманювати; зраджувати» $\rightarrow$ être peint en jaune «бути обманутим, зрадженим», bouffer la rate «битися» $\rightarrow \boldsymbol{B o u f f e}(\boldsymbol{e z}) \mathbf{l a}$ rate! «Ну ж бо! (заклик підбадьорення під час бійки)»; faire des misères «набридати; створювати неприємності комусь» $\rightarrow$ faire la misère à qqn «погано ставитися до когось», faire le ménage «прибирати; наводити 
лад» $\rightarrow$ faire des ménages «займатися дрібними справами без зацікавленості»);

6) контамінація (9 ФО - 3,5\%) - суміщення двох узуальних ФО в одній неологічній ФО з новою структурою, новим смислом і новою образністю, яке здійснено за трьома когнітивними моделями: перехрещення, за якого в контамінаційний процес вступають дві ФО, для яких характерна спільна семантика й структура; у разі породження неологічної ФО відбувається обов'язкова елімінація одного із МП компонентів вихідних ФО, напр.: retour de manivelle «удар у відповідь» + tour de bâton «незаконний дохід» $\rightarrow$ retour de bâton «непередбачений вчинок у зворотному напрямку»; приєднання, під час якого ІП неологічної ФО містить образи, спроєктовані з усіх МП компонентів вихідних ФО; при цьому відбувається перерозподіл структурносинтаксичних зв'язків між компонентами, напр.: avoir raison «мати рацію» + pas pour (un) deux sous «зовсім» $\rightarrow$ ne pas avoir pour deux sous de raison «бути абсолютно неправим»; поширення, за якого одна базова ФО поширює свою структуру одним із компонентів іншої ФО, напр.: en avoir dans l'aile «бути в скрутній ситуації» + boire un coup «хильнути» $\rightarrow$ avoir un coup dans l'aile «бути напідпитку».

Вивчення власне семантичних механізмів породження неологічних ФО показало залежність семантики ФО від текстового оточення. Основною когнітивною операцією із семантичного оновлення концептуального значення узуальної ФО $\epsilon$ неосемантизація, за якої шляхом «висвічування» або «згасання» певних образів вихідних МП неологічна ФО отримує нове семантичне значення. Аналіз фактичного матеріалу дозволив виявити п'ять когнітивних моделей, які відображають:

1) зміну вихідного концептуального значення (38 ФО - 46\%), яку супроводжує метонімічне (напр.: prendre une prune «пропустити стаканчик (алкоголю)» $\rightarrow$ «порушити закон») або метафоричне переосмислення (напр.: un délit de sale gueule «порушення прав людини через те, що вона іммігрант» $\rightarrow$ «знущання або зневага до тварини через ії зовнішній вигляд або наявні в суспільстві забобони»);

2) узагальнення вихідного концептуального значення (21 ФО $25 \%$ ), напр.: ne pas avoir les yeux en face des trous «погано почуватися зранку після випитого багато вчора» $\rightarrow$ «прокинутися в поганому настрої»;

3) звуження вихідного концептуального значення (11 ФО - 13\%), напр.: atomes crochus «спільні уподобання, які пов'язують людей» $\rightarrow$ «чинник дружби, загадковий фактор взаємної симпатії»; 
4) актуалізацію застарілого образу і його подальше семантичне оновлення (9 ФО - 11\%), напр.: arrivé par le coche «новоприбулий» $\rightarrow$ «наївний; селюк»;

5) розвиток антонімічного значення (4 ФО - 5\%), напр.: faire le lit $d e q q n$ «прокласти комусь шлях» $\rightarrow$ «діяти проти чиїхось інтересів».

Отже, вважаючи контекст необхідною умовою формування нового значення ФО, ми виходимо у сферу досліджень динамічного характеру семантики мовної одиниці у синхронії, згідно 3 якими вона розглядається як «рухомий, динамічний конструкт», а мовне значення будується в контексті, «в режимі реального часу», а не 3 готових стереотипізованих когнітивних моделей.

\section{ВИСНОВКИ}

Неологічні ФО постають як лінгвосеміотичний феномен, який фіксує в усталеній формі особливості психоемоційної та раціональної дійсності, рефлексивного досвіду етносу, стереотипи етносвідомості й архетипи колективного позасвідомого. Власне через це вони стають предметом поліпарадигмальних досліджень, які вивчають зв'язки й відношення ФО з мовленням, спілкуванням, діяльністю, психікою, культурою тощо.

Вивчення процесу вторинної фразеологізації зумовило насамперед потребу в розмежуванні понять фразеологічної деривації та словотвірної деривації на базі фразеології. Аналіз фактичного матеріалу довів також, що явище фразеологічної деривації вирізняється від фразеологічної варіативності, яка передбачає лише формальну модифікацію без зміни значення іiі позначуваного, оказіонального вживання модифікованих ФО, яке виявляється лише в певному контексті й не закріплюється узусом, та дефразеологізаuіï, яка взагалі руйнує ідіоматичне значення ФО й розкладає його на складники. Основним критерієм їхньої диференціації постає поява нового семантичного значення або нового семантичного компонента у структурі неологічної ФО.

Щодо типів вторинної фразеологізації, то із функціональносемантичного погляду виокремлюємо одноразову та багаторазову лінійну, одноразову та багаторазову об'ємну, кожна з яких вирізняється кількістю новоутворених ФО та ступенем продуктивності їхнього творення.

Детальне вивчення лінгвокогнітивних механізмів породження неологічних ФО сучасної французької мови дозволило визначити два типи модифікацій, а саме: 1) структурно-семантичні (ампліфікація, доповнення, елімінація, калькування, граматична трансформація, 
контамінація) та 2) власне семантичні (неосемантизація без зміни структури узуальної ФО).

Отже, дослідження процесу вторинної фразеологізації із когнітивної точки зору показало, що в основі іï механізмів лежать комунікативнопрагматичні чинники, когнітивно зумовлені й мотивовані намірами мовців. Засновані на цілеспрямованій видозміні усталеної структури ФО та/або їхньої семантики, ці трансформації спрямовані не лише на оживлення та посилення їхньої виразності, а й на нове відображення сприйняття людиною відомого вже їй об'єкта або явища. В аналізі мотиваційних основ творення одиниць вторинної фразеологізації полягає перспектива нашого дослідження.

\section{АНОТАЦІЯ}

Сучасні когнітивно спрямовані дослідження мови формують нові принципи й підходи до аналізу мовних явищ, зокрема неологізації мови. Саме в аналізі лінгвокогнітивних механізмів породження одиниць вторинної фразеологізації сучасної французької мови полягає мета запропонованої розвідки. Насамперед автором визначено сутність окресленого явища, яке полягає у модифікації узуальних ФО на формальному та/або семантичному рівнях $\mathrm{i}$ внаслідок якого формуються одиниці, що претендують на статус неологічних. Показано, за якими критеріями слід вирізняти вторинну фразеологізацію від фразеологічної варіативності, оказіонального вживання та дефразеологізації. За кількістю новоутворених ФО та ступенем продуктивності їхнього творення виокремлено чотири типи вторинної фразеологізації: одноразова та багаторазова лінійна, одноразова та багаторазова об'ємна. Шляхом побудови ІП, в якому породжено нове концептуальне значення, визначено два типи лінгвокогнітивних механізмів: структурно-семантичні та власне семантичні. Доведено, що в результаті процесу вторинної фразеологізації породжено нові ФО, призначення яких полягає у виразному відображенні нового сприйняття людиною уже відомого об'єкта або явища.

\section{ЛITЕРАТУРА}

1. Баран Я.А. Фразеологія у системі мови : монографія. ІваноФранківськ, 1997. 176 с.

2. Биренбаум Я.Г., Сидякова Н.М. Отражение вариантности фразеологических единиц в словаре устойчивых сравнений английского языка. Вариативность в германских языках : тезисы докладов и сообщений Всесоюз. конф. Калинин, 1988. С. 185-186.

3. Васильченко В. Українська фразеологія. Київ, 2000. 96 с. 
4. Денисенко С.Н. К вопросу взаимосвязи слово- и фразообразования. Филологические науки. 1985. № 1. С. 54-60.

5. Денисенко С.Н. Фразеологическая деривация как системный и коммуникативный феномен : дисс. на соискание науч. степени док. филол. наук : спец. 10.02 .04 «Германские языки». Львов, 1993. 415 с.

6. Джаграева М.Л. Коммуникативно-прагматические особенности фразеологической деривации : дис. на соискание науч. степени канд. филол. наук : спец. 10.02.19 «Теория языка». Ставрополь, 2005. 182 с. URL: http://cheloveknauka.com/

7. Керимзаде Н.К. Фразеологическая деривация : автореф. дисс. на соискание науч. степени канд. филол. наук : спец. 10.02.04 «Германские языки». Москва, 1984. 23 с.

8. Колшанский Г.В. Соотношение субъективных и объективных факторов в языке. Москва, 1975. 232 с.

9. Копыленко М.М., Попова З.Д. Очерки по общей фразеологии. Воронеж, 1972. $124 \mathrm{c}$.

10. Красных В.В. Этнопсихолингвистика и лингвокультурология. Москва, 2002. 284 с.

11. Кунин А.В. Курс фразеологии современного английского языка. Москва, 1996. 381 с.

12. Ларин Б.А. Очерки по фразеологии (О систематизации и методах исследования фразеологических материалов). История русского языка и общее языкознание. Москва, 1977. С. 125-149.

13. Мізін К.І. Компаративні фразеологічні одиниці сучасної німецької мови: шляхи утворення та ідеографія : автореф. на здобуття наук. ступеня канд. філол. наук : спец. 10.02.04 «Германські мови». Київ, 2004. 20 с.

14.Пташник С.Б. Фразеологічні модифікації: термінологічні проблеми. Вісник Львів. ун-ту. Серія Іноземні мови. 2011. Вип. 9. C. $112-120$.

15. Телия В.Н. Что такое фразеология? Москва, 1966. 86 с.

16. Телия В.Н. Русская фразеология. Семантический, прагматический и лингвокультурологический аспекты. Москва, 1996. 288 с.

17. Уманець А., Стадник О. Типологічні особливості фразеологічних синонімів в англійській та українській мовах. Наукові пращі Кам'янецьПодільського держ. пед. ун-ту. Філологічні науки. Кам'янецьПодільський, 2001. Вип. 5. С. 49-52.

18. Флоренский П.А. Термин. Вопросы языкознания. 1989. № 1. C. $121-133$.

19. Ханпира Э. Об окказиональном слове и окказиональном словообразовании. Развитие словообразования современного русского языка : сб. науч. тр. Москва, 1966. С. 153-166. 
20. Чередниченко В.О. Інноваційна фразеологічна вербалізація в англійській мові (лінгвокогнітивний та соціолінгвістичний параметри) : дис. на здобуття наук. ступеня канд. філол. наук : спец. 10.02.04 «Германські мови». Запоріжжя, 2005. 220 с. URL: http://www.allbest.ru/.

21. Шанский Н.М. Лексикология современного русского языка. Москва, 1972. 328 с.

22. Bähler U. Réflexions à partir de renouvellements de locutions stéréotypées. Languages. No. 137. 2000. P. 46-62. URL: www.persee.fr.

23. Bally Ch. Traité de stylistique française. Genève, 1951. 595 p.

24. Bolly $\mathrm{C}$. Les unités phraséologiques : un phénomène linguistique complexe?: thèse de doctorat. Louvain-la-Neuve, 2008. 344 p.

25. Curat $H$. Les déterminants dans la référence nominale et les conditions de leur absence. Genève, 1999. $350 \mathrm{p}$.

26. Galisson R. Les palimpsestes verbaux: des révélateurs culturels remarquables mais peu remarqués. La locution en discours. Cahiers du français contemporain. 1995. No. 2. P. 41-64.

27. Haßler G., Hümmer Ch. Figement et défigement polylexical: l'effet des modifications dans des locutions figées. Linx: Revue des linguistes de l'université Paris X. 2005. No. 53: Le semi-fegement. P. 103-119.

28. Klein J.R. Le figement dans les proverbes et les expressions verbales: un débat qui n'est pas encore ... figé. Nouveaux apports à l'étude des expressions figées / Conde Tarrío G. Cortil-Wodon. 2007. P. 129-156.

\section{Information about the author:} Moisiuk V. A., Doctor of Philological Sciences, Associate Professor, Associate Professor at the Department of Roman Philology and Translation Yuriy Fedkovych Chernivtsi National University 2, Kotsubynskyy str., Chernivtsi, 58001, Ukraine 